\title{
Expressive Speech Acts In The Speech Of Autistic Children
}

\author{
Endang Sumarti ${ }^{1}$, Dwi Astuti Wahyu Nurhayati ${ }^{2}$, and Yahmun ${ }^{3}$ \\ \{endangsumarti@yahoo.com ${ }^{1}$,dwiastuti507@gmail.com², yahmun_jha@yahoo.com ${ }^{3}$ \} \\ 1,3 IKIP Budi Utomo, Malang, Indonesia \\ ${ }^{2}$ IAIN Tulungagung, Indonesia
}

\begin{abstract}
One of utterences used by autistic children in communicating their ideas is expressive speech act. This paper aims to describe the forms and functions of expressive speech acts in the speech of autistic children. This study used qualitative approach. The data obtained were the speech of autistic children, constructing the forms and functions of expressive speech acts. The data were collected by using recording and observation techniques. To analyze the data, the interactive model analysis was deployed. The analysis resulted in two major findings. Firstly, the forms of expressive speech acts in the speech of autistic children included the statement of happiness, unhappiness, and gratitude. Secondly, the functions of expressive speech acts in the speech of autistic children were to express happiness, anger, and fear.
\end{abstract}

Keywords: Expressive speech acts, speech, autistic children

\section{INTRODUCTION}

Autism is a developmental disorder occurring in childhood, which makes someone unable to perform social interaction. This condition makes someone feel as if he lived in his own world [1]. Autistic children experience a qualitative disorder in social interaction, communication, and behavior [2]. Autism is one of the disorders characterized by the delays in cognitive, communication, interest to social interaction, and behavior [3]. Autistic children experience difficulties in expressing the words they want or need to say [4];[5];[6]. As a developmental disorder, autism prevents children to interact socially, which makes them feel like living in the world of themselves [7].

Autistic children encounter a communication disorder. This disorder can be seen from their speech delay in the form of incomprehensible language use [8]. Disorders in communication, social interaction, and imagination often correlate each other so that a disorder can be viewed as a trio [5]. Communication refers to someone's behaviors that send and receive messages in a distorted way. It occurs in a particular context having a certain effect, and there is a chance to provide feedbacks [9]. In daily life, humans use language as a means of communication [10]. Through language, the speaker delivers the message so that it can be understood by his partner based on the idea on his mind [11].

Communication performed by autistic children is commonly imperfect if compared to other children in general [12]. Communication and language used by autistic children are dissimilar to other children at their age. Autistic children encounter difficulties in both verbal 
and non-verbal communication. It is hard for them to deliver the message to other people. For instance, if autistic children want to drink milk, they will probably walk to and fro or keep silent. They also may cry and eventually ask their partners to offer something they want. In fact, autistic children are unable to express their wants spontaneously [13]. Expressive speech act is one of the speech acts used by autistic children to interact with their partners. Expressive speech acts in the speech or autistic children, therefore, are worth studying. This study proposed to investigate the forms and finctions of expressive speech acts used by autistic children.

\section{METHOD}

This qualitative research deployed clinical pragmatics approach. The researcher was the key instrument of this research. The primary data source of this research was the speech of autistic children in Malang, east Java. The data covered the words and sentences, which constructed the forms and functions of expressive speech acts. The data were collected by using recording and observation techniques. The data analysis, which used interactive model analysis, comprised of data collection, data reduction, data display, verification, and conclusion. This interactive model is adopted from Miles \& Huberman qualitiative data analysis [14].

\section{RESULT AND DISCUSSION}

\subsection{RESULT}

\subsubsection{The Forms of Expressive Speech Acts in the Speech of Autistic Children}

The forms of expressive speech acts described in this research included the statement of (1) happiness, (2) unhappiness, and (3) gratitude. The explanation of expressive speech acts of autistic children is as follows.

\section{a. The Statement of Happiness}

The utterance of happiness is a speech act that expresses the feeling or mental condition when facing (sensing) something. The statement of happiness is utilized when autistic children can answer their partners' questions correctly, or the intended answer can be comprehended by their partners. The following excerpts show the statement of happiness.

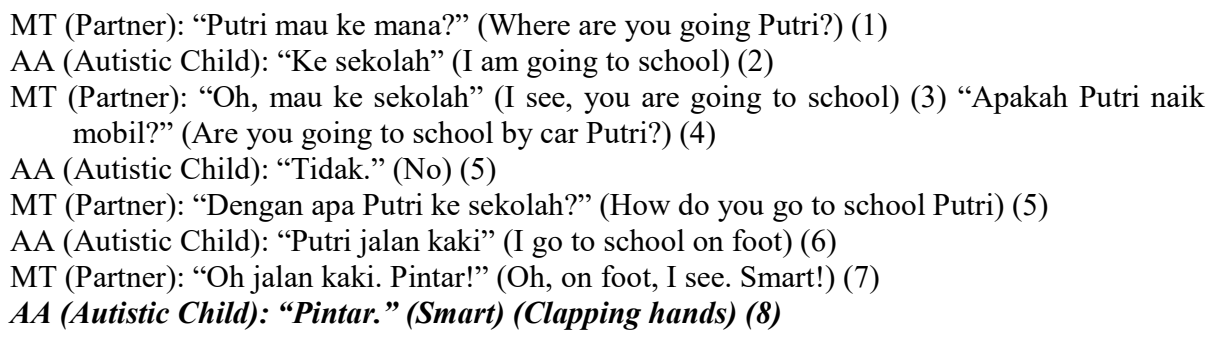

The above-mentioned excerpts revealed the use of expressive speech acts in the speech of autistic children. The speech (8) indicated the statement of happiness experienced by autistic children. The use of the word pintar (smart) while clapping hands in the speech (8) showed the happiness of autistic children since she could answer her partner's question well. To express happiness, it was tough for autistic children because they have constraints on 
communication.

b. The Statement of Unhappiness

The expression of unhappiness is used by autistic children in interacting with their partner. The excerpts are as follows.

MT (Partner): "Apakah ini Ira?" (Is this Ira?) (1) (Pointing at Ira who is sitting)

AA (Autistic Child): "Ya." (Yes) (2)

MT (Partner): “Apakah ini Bu Kiki?” (Is this Ms. Kiki?) (3)

AA (Autistic Child): "Ya." (Yes) (4)

MT (Partner): "Ya. Apakah Koko pernah melihat harimau?" (Yes. Have you ever seen tiger Koko?) (5)

AA (Autistic Child): “Tidak!” (No) (6) “Tidak, haaa." (No) (7) (Raising his hands and hitting the table with his right hand)

MT (Partner): "Oh, tidak." (Oh, no) (8)

AA (Autistic Child): "Sakit kepala." (Headache) (9) (Holding his head with his hands)

MT (Partner): "Koko, apakah ini Hermin?" (Koko, is this Hermin?) (10)

AA (Autistic Child): "Ya. Sakit kepala" (Yes. Headache) (11) (Wiping his nose, then holding his head)

The speech of autistic children in the excerpts above were the forms of expressive speech acts. The utterances that express unhappiness are depicted in the speech (6) and (7). The utterances revealed that Koko was unhappy being questioned by his partner whether he liked seeing a tiger. Koko expressed unhappiness over the question by saying: "Tidak!" (No) (6) “Tidak, haaa," (No) (8) (while raising his hands and hitting the table with his right hand). Another thing disliked by autistic children was that when the partners asked them repeatedly. Due to the repeated questions, they expressed unhappiness. The speech (9) and (11) indicated this symptom. The data showed that a dislike of the autistic child to receive questions from her partner was expressed by saying sakit kepala (headache) while holding the head.

\section{c. The Statement of Gratitude}

Gratitude is a contented expression sensed by autistic children over something they newly receive from their partners. The following excerpts depict the statement of gratitude.

AA1 (Autistic Child 1): "Hasan, Hasan ini." (Hasan, this is Hasan) (1) (Passing the soup noodle).

AA2 (Autistic Child 2): "Diam." (Be quiet) (2)

AA1 (Autistic Child 1): "Hasan jatuh, ini." (Hasan, it fell down) (3) "Ambil." (Take it) (4) (Informing Hasan that his bag fell down and asking him to take his bag under the table).

AA2 (Autistic Child 2): "Diam." (Be quiet) (Hasan was silent while receiving the noodle he ordered)

AA1 (Autistic Child 1): "Sebul dulu!" (Blow it first!) (5) (Telling Hasan that the noodle is hot by asking him to blow his noodle, and leaving Hasan's table)

AA2 (Autistic Child 2): "Diam." (Be quiet) (6) (Receiving the noodle)

MT (Partner): "Bilang apa sama Udin, Hasan?" (What can you say to Udin, Hasan?) (7) "Terima kasih Udin." (Thank you Udin) (8)

AA2 (Autistic Child 2): “Terima kasih Udin” (Thank you Udin) (9)

The speech of autistic children in the excerpt [3] represented the statement of gratitude. In fact, the statement of gratitude delivered by Hasan to Udin was grueling in its production. In the speech (7), the partner asked Hasan about what to express after receiving something from Udin. However, since Hasan did not immediately answer the question, in the speech (8) the partner provided an example of the expression that Hasan must say to Udin. In the speech (9) 
Hasan showed his gratitude to Udin after he received the soup noodle.

\subsubsection{The Functions of Expressive Speech Acts in the Speech of Autistic Children}

The speech to express feelings is a speech act that states what is sensed by the speaker. In the context of this research, autistic children encountered difficulties in expressing feelings. Nevertheless, with the intensive interaction of expressive speech acts, autistic children are able to express their feelings. Expressive speech acts of autistic children found in this research included the speech to express happiness, anger, and fear. The analysis of the three functions of expressive speech acts is presented in the following explanation.

\section{a. Expressing Happiness}

The statement of happiness is a speech act that expresses feelings or mental conditions when someone faces (feels) something pleasant. Happiness is usually expressed by autistic children when they are satisfied with something they have done, or when they are feeling something they like. This research suggested that the speech of autistic children was to express happiness as revealed in the following excerpts.

MT (Partner): “Jus strowberi. Enak Ko rasanya Ko?” (Strawberry juice. Is it delicious Ko?) (1)

AA (Autistic Child): “Enak siip." (Delicious) (2)

MT (Partner): "Enak sekali. Mak..." (It is so delicious. Yum...) (3)

AA (Autistic Child): "Maen" (A guessed answer) (5)

MT (Partner): "Mak...nyus.” (Yummy) (5) "Heh Ko, Koko makan sate apa?" (Ko, what satay do you eat?) (6)

Autistic Child: "Sate, gulii, enak." (Satay, delicious) (7)

The excerpts above showed the communicative function of expressing happiness. In the speech (2), Koko said to his partner that the strawberry juice was "enak siip" (delicious). In the speech (6) the partner asked Koko about what satay did Koko eat. However, since Koko only remembered the taste of satay, as depicted in the speech (7), Koko replied the partner's question by saying "Sate, gulii, enak" (Satay was delicious), to clarify the taste of satay he ate. The speech, uttered by Koko, is one of the speech functions, that is, to express happiness. It was articulated by Koko, an autistic child, in response to the tasty food he ate.

\section{b. Expressing Anger}

Anger is an annoyance that appears in response to the anxiety, which is deliberated as a threat. The speech to express anger is conveyed by autistic children when they think the partners behave disapprovingly, or they are treated improperly.

This kind of speech is exemplified in the following excerpts.

MT (Partner): “Ayo sekarang kita nyanyi bersama-sama!” (Now let's sing together!) (1) “Aku seorang Kapiten." (I am a captain) (2) ) "Aku seorang kapiten, mempunyai pedang panjang..." (I am a captain, I have a long sword...) (3)

AA (Autistic Child): "Ha ...ah, ha ...eh." (4) (Angry)

MT (Partner): "Hei kenapa marah? Hei siapa hari ini yang sedih?" (Hey, why are you angry? Hey, who is sad today?) (5) "Ayo kita menyanyi lagi, biar sehat dan tidak sedih!" (Let's sing again, so you are healthy and fun!) (6)

The communicative function to express anger is represented in the speech (4). In this speech, autistic children expressed anger by saying unclear utterances while stomping his feet on the floor as the signal of their anger.

\section{c. Expressing Fear}


In addition to expressing happiness and fear, the speech of autistic children is to express fear as well. Autistic children got frightened and they did not follow the partners' order when they are asked to enter the dark path. The following excerpts showed the speech of autistic children in expressing fear.

MT (Partner): “Ayo ke sana.” (Let's go there) (1) (It's Nanta's turn to enter the dark path in the playground)

AA (Autistic Child): "Gak mau, gak mau, gak mau." (No, no, no) (2) (Crying)

MT (Partner): "Gak apa-apa.” (It is okay) (3) Ayo, diKoba!” (Come on, try it!) (4)

AA (Autistic Child): "Takut aku, takut" (I am scared) (5)

The excerpts above exemplified how autistic children articulated their fear. In the speech (2), the expression "Gak mau, gak mau, gak mau," (No, no, no) were uttered by autistic children to reject the order given by the partner; for example, to enter the dark path.

\subsection{DISCUSSION}

The data suggest that autistic children are able to express their feelings although in the form of simple speech acts. The forms of expressive speech acts uttered by autistic children were the statement of happiness, unhappiness, and gratitude. Meanwhile, the function of expressing feelings was conveyed by autistic children in diverse purposes such as expressing happiness, anger, and fear. By identifying the forms and functions of the autistic children's speech acts, and figuring out the difficulties they encounter in expressing their wants, the partners (parents, therapist, and teachers) should train autistic children to apply those language functions with diverse partners in varied situations.

The findings are in line with Handoyo (2009) stating that it is crucial to teach self-help skills to autistic children. By knowing expressive speech acts, the partners can assist autistic children by teaching the expressive language. Teaching expressive language is defined as providing autistic children with the ability to remember and comprehend anything recorded in their memory to be expressed. In a different environment, autistic people need to be approached properly (Peeters, 2009). Regarding the behavioral disorder, autistic children need to get intervention or therapy in creating a better condition [2].

In addition, this study is also in line with study of Social Interactive Strategy Instruction to Autistic Children. This study finds that in order to make autistic children there were several strategy in teaching social interaction to autistic children by their parents. They were imitating the words said by others, giving notes on the study table, asking them to play in the yard, and introducing them to guest [15][16].

\section{CONCLUSION}

Expressive speech act is a kind of speech acts that are related to the expression of the psychological attitude of the speaker towards the partners in particular situations. In fact, it was found that expressive speech acts of autistic children included the statement of happiness, unhappiness, and gratitude. In addition, autistic children used expressive speech acts to express happiness, anger, and fear.

The use of variative expressive forms and fuctions of speech acts is a social fact that we should understand the way autistic children interact in a social life. Therefore, I belive that this study will enrich theoretical framework of Clinical Pragmatics, especially speech atcs of autistic children and will help parents, teachers, and therapies in understanding austistic children's expressive speech acts. 


\section{REFERENCES}

[1] D. . Prasetyono, Serba Serbi Anak Autis (Autisme dan Gangguan Psikologis Lainnya: mengenal, menangani, dan mengatasinya dengan Tepat dan Baik). Yogyakarta: DIVA Press, 2008.

[2] L. S. A. Prasetyoningsih, "Pengembangan Tindak Bahasa Terapi Dalam Intervensi Anak Autis Spektrum Perilaku," Litera, vol. 15, no. 1, pp. 120-127, 2019.

[3] G. A. Veskarisyanti, 12 Terapi Autis Paling Efektif dan Hemat: Untuk Autisme, Hiperaktif, dan Retardasi Mental. Yogyakarta: Pustaka Anggrek, 2008.

[4] Priyatna, Amazing Autism: Memahami, Mengasuh, dan Mendidik Anaak Autis. Jakarta: Gramedia, 2010.

[5] T. Peeters, Panduan Autisme Terlengkap: Hubungan antara Teoretis dan Intervensi Pendidikan bagi Penyandang Autis. Jakarta: Dian Rakyat, 2009.

[6] Yuwono, Memahami Anak Autis: Kajian Teoretik dan Empirik. Bandung: Alfabeta, 2009.

[7] E. Sumarti, "Pendidikan karakter anak autis melalui dongeng," J. Kaji. Bahasa, Sastra Indones. dan Pembelajarannya, vol. 2, no. 1, pp. 82-87, 2018.

[8] Maulana, Anak Autis: Mendidik Anak Autis dan Gangguan Mental Lainnya menuju Anak Cerdas dan Sehat. Yogyakarta: Katahati, 2007.

[9] S. Robiah, A. Syukur Ibrahim, and A. Rofi'uddin, RESPON TUTUR SISWA AUTIS TERHADAP TUTUR DIREKTIF GURU DALAM INTERAKSI PEMBELAJARAN DI KELAS, vol. 44. 2016.

[10] Defina, "TINDAK TUTUR EKSPRESIF PADA ANAK-ANAK SAAT BERMAIN BOLA DI LAPANGAN,” J. Kaji. Bhs., vol. 7, no. 1, pp. 69-85, 2018.

[11] E. Sumarti, "GANGGUAN KOMUNIKATIF DALAM TUTURAN LISAN ANAK AUTIS," 2017.

[12] A. M. Haryadi, "Kompetensi Thematic Role Anak Autis dalam Memproduksi Kalimat," J. Pendidik. Bhs. Indones. Bhs. Drh., vol. 6, no. 2, pp. 11-21, 2017.

[13] E. Sumarti and U. Salamah, "Tindak Tutur Direktif Anak Autis," 2017.

[14] Miles \& Huberman, Qualitative data analysis: An expanded sourcebook (3rd ed.). 2014.

[15] A. R. K. Siwi and N. R. N. Anganti, "Strategi Pengajaran Interaksi Sosial pada Anak Autis,” Indig. J. Ilm. Psikol., vol. 2, no. 2, pp. 184-192, 2018.

[16] K. Saddhono and M. Rohmadi, "A Sociolinguistics Study on the Use of the Javanese Language in the Learning Process in Primary Schools in Surakarta, Central Java, Indonesia." Int. Edu. Stu., vol. 7 no.6 pp 25-30, 2014 